УДК 78.071.1(477):37.011.3](=161.2)“19”

DOI:

Наталія Кобрин, кандидат історичних наук, викладач-методист Львівської середньої спеціалізованої музичної иколи-інтернату імені С. Крушельницької

\title{
КОНЦЕПТУАЛЬНІ ІДЕЇ МУЗИЧНОЇ ПЕДАГОГІКИ СТАНІСЛАВА ЛЮДКЕВИЧА В КОНТЕКСТІ ЕПОХИ
}

Педагогічна частина спадщини С. Людкевича є дуже вагомим явищем у контексті розвитку украйнськоі системи музичної освіти та виховання в XX cm. У статті проаналізовано триєдність організаційного, концептуально-методичного й дидактичного напрямку музично-педагогічної діяльності мития. Автор розглядає опорні ідеї й поняття музичної педагогіки С. Людкевича -музика як суть інтелекту українців, їі етичний сенс, природний співучий інстинкт дитини, “омузикалення”, синтетична освіта музиканта, що засвідчують увагу композитора до музичного виховання як до загально суспільної проблеми.

Ключові слова: музично-педагогічна спадщина; професійна музична освіта; Вищий музичний інститут ім. Миколи Лисенка; С. Людкевич; Галичина.

Табл. 1. Літ. 16.

Nataliya Kobryn, Ph.D.(History), Lecturer of the Solomiya Krushelnytska Special Secondary Music School of Lviv

\section{THE FUNDAMENTAL IDEAS OF STANISLAV LYUDKEVYCH MUSICAL PEDAGOGY IN THE CONTEXT OF THE EPOCH}

As a part of the Pan-European movement in order to improve the system of musical education, the pedagogical heritage of Ukrainian musicologist and composer Stanislav Lyudkevych had a significant influence on the development of Ukrainian musical pedagogy of the twentieth century. Many facts on Stanislav Lyudkevych's activity in musical pedagogy have acumulated in the modern scientific literature and numerous memories. It's time to systematize this facts and to analyze the complete concept of national musical upbringing in his heritage. The first period of the Stanislav Lyudkevych life (until 1939) was determining in relation to his social and scientific activity on musical education of Ukrainians in Halychyna. The musical pedagogy of S. Lyudkevich combined the organizational activities as a director and an inspector of Mykola Lysenko Higher Music Institute, as well as the scientific and methodological heritage (articles and reports) and the didactic materials (textbooks on solfeggio, music theory, etc.) in which his views on musical education and pedagogical principles are revealed. S. Lyudkevych discussed on mass and professional musical education as well as on musical upbringing of society in generally and very specialized topics (solmization, musical dictation, etc.) in his papers on musical pedagogy. While interpreting musical education as a social problem, the composer's concept is based on five important world-view and aesthetic fundamentals: music is "the essence of the intellect of Ukrainians", the ethical understanding of music ("kalokagatiya"), "the natural singing instinct of child" as a background in the early training, complex education as a need in professional music. As it affirms the content of textbooks on solfeggio, music theory and musical aesthetics, integrity is a main feature of S. Lyudkevych's musical pedagogy in the professional area. Training of the "acoustic axis", formating of a coherent and consistent system of knowledge, understanding of logical connections of the musical system, developing of thinking are main aims of musical education according to S. Lyudkevych.

Keywords: musical and pedagogical heritage; professional musical education Mykola Lysenko Higher Music Institute; Stanislav Lyudkevych; Halychyna.

П остановка проблеми. Станіслав Людкевич - український композитор і музиколог минулого століття справив визначальний вплив на розвиток української музичної педагогіки й виховання в Галичині. Його діяльність розгорталася на тлі всеєвропейського руху з метою вибудувати i вдосконалити систему загальної музичної освіти як спосіб різнобічного формування особистості й збереження власних національних мистецьких традицій (Болгарія - Б. Трічков, Німеччина К. Орф, Угорщина - 3. Кодаї, Б. Барток,
Швейцарія - Е. Жак-Далькроз тощо). В контексті української культури першої половини ХХ ст. його музично-педагогічна спадщина $є$ хронологічно синхронною та функціонально співзвучною до ідей В. Барвінського, В. Верховинця, Ф. Колесси, М. Леонтовича, М. Лисенка, Я. Степового, К. Стеценка, О. Суховерської, Г. Терлецького, Б. Яворського та ін.

Аналіз останніх досліджень і публікацій. Тема “С. Людкевич - педагог та його спадщина" в сучасній науковій літературі розкрита лише частково. Зазвичай, це огляди основних музично- 
дидактичних матеріалів і статей митця (Л. Баб’юк [1], I. Бермес [2]), факти педагогічної діяльності в контексті життєвого шляху (Л. Баб'юк [1], О. Михайличенко [14], 3. Штундер [16]) чи спогади, збагачені особистими деталями й цікавинками (В. Витвицький [3], І. Гамкало [4], T. Гнатів [6], М. Ластовецький [9], Є. Цегельський [15]). У ІІ т. двотомового видання “Станіслав Людкевич. Дослідження, статті, рецензії, виступи” [ $10 ; 11]$ були надруковані основні статті митця зі сфери музичної педагогіки, хоча його посібники й матеріали до сьогодні залишаються раритетами в літографіях та рукописах 20 - 30-х pp. ХХ ст.

Мета статті. Все це дозволило акумулювати чимало важливих фактів життепису С. Людкевича (вагомим їх джерелом $є$ вже згадані спогади й сторінки монографії 3. Штундер) та частково поширювати в наукових колах інформацію про зміст його музичнопедагогічних публікацій. Тим більшої ваги набуває потреба проаналізувати й систематизувати спадщину С. Людкевича 3 точки зору цілісної концепції національного музичного виховання та освіти, на тлі тогочасної музично-педагогічної думки й тенденцій розвитку української культури.

Виклад основного матеріалу дослідження. Музично-педагогічна діяльність С. Людкевича охоплює майже століття, однак $є$ нерівномірною щодо можливостей різнобічної праці й музичносуспільних обов'язків самого композитора. В ній виразно виділяються два хронологічні етапи: I період - до 1939 р. є ключовим для формування його музично-педагогічних концепцій та педагогічно-організаційної діяльності митця; II період - після 1939 р., радянський етап, коли активність музиканта іде на спад. Постать С. Людкевича в українській музичній педагогіці показова також із позиції триєдності організаційного, концептуально-методичного (статті, доповіді) і дидактично-практичного (посібники і матеріли) напрямків.

Організаційно-педагогічну лінію у діяльності С. Людкевича найкраще розкривають етапні дати, які можна узагальнити за відомою літературою: 1902 р. - С. Людкевич у складі музичної комісії товариства “Сокіл” був біля витоків Вищого музичного інституту (BMI) ім. Миколи Лисенка та опікувався формуванням його навчальноосвітнього плану [7, 9 - 15]; 1910 - 1914 рр. С. Людкевич обіймав посаду директора ВМІ ім. Миколи Лисенка, значно розширюючи його діяльність і сприяючи зростанню професійності в музичній освіті (вдосконалення навчальних планів, заснування власного стипендійного фонду, закупівля музичних інструментів, організація систематичних концертів) [16,217]; 1919-1939 pp. - він став інспектором філій ВМІ ім. Миколи Лисенка, до сфери відповідальності якого входило координувати музично-освітню діяльність мережі 3 близько 20 філій та експонованих класів музичного інституту по всій Галичині, станом на середину $30-\mathrm{x}$ рр. ХХ ст. [8, 10].

Обсяг обов'язків митця частково дозволяє зрозуміти географія філій та експонованих класів BMI: Борислав, Городок, Дрогобич, Жовква, Золочів, Коломия, Перемишль, Рава-Руська, Рогатин, Самбір, Сокаль, Станіславів, Стрий, Тернопіль, Ходорів, Чортків, Яворів, а також на передмістях Львова (Богданівка, Личаківська, Стрийська). Кожна 3 них двічі на рік проводила іспити з усіх предметів, при тому у великих філіях вони могли тривати кілька днів. Стиль роботи С. Людкевича на посаді інспектора найповніше описав В. Витвицький, згадуючи його щопіврічні відвідини Перемишля: “Ані я, ні хто інший з-поміж учителів, членів іспитових комісій, не провадив так точно іспитових протоколів, як наш інспектор. Кожна гама, кожний пасаж і кожний твір були точно занотовані з маленькими позначками якости виконання" $[3,206]$.

Статті, доповіді, огляди, рецензії, посібники та матеріали С. Людкевича (концептуальнометодичний і дидактично-практичний напрям діяльності) виявляють грунтовне знання автором світової загально педагогічної думки й найновішої музично-дидактичної літератури, дозволяють 3'ясовати його погляди на масове музичне виховання та професійну музичну освіту, розкривають еволюцію матеріалів автора від загальних проблем музичного виховання суспільства у статті "Наші шкільні співаники" (1905) чи широкої читацької аудиторії “Загальних основ музик” (1921) до вузько спеціалізованих тем - система сольмізації, диктант тощо, як-от у статтях "Критичні замітки в справі науки сольфеджіо і музичного диктанту в музичних школах" (1929), "Proba Krytycznego ujęcia kwestji solmizacji i jej reformy” (1929), "Розклад матеріалу науки сольфеджіо” (1930). Загалом митцеві належить близько 20 статтей, матеріалів та підручників зі сфери музичної педагогіки і виховання, багато з яких були написані та видані у перший період його діяльності, до 1939 р.

Основою музично-педагогічної концепції C. Людкевича $\epsilon$ кілька вагомих понять світоглядного, педагогічного й естетичного плану, які значною мірою розкривають наскільки великою була увага митця до музичного виховання як загально суспільної проблеми: 
музика - це “суть інтелекту української нації; музика має етичний вплив, який позначається давньогрецьким терміном “кальокагатія”; опорою увихованні має бути природній співучий інстинкт дитини; “омузикалення” є дуже важливим на початках освіти; справді фаховий музикант повинен отримати різнобічну синтетичну освіту.

1. Визначення музики як “суті інтелекту” української нації появляється в одній із перших статей С. Людкевича на музично-педагогічні теми “Кілька слів про потребу засновання укрансько-руської музичної консерваторії у Львові” (1902), в якій він обгрунтовував необхідність національної професійної музичної освіти та утворення відповідних установ $[11,255]$. Хоча розробка й взаємопов'язання понять “інтелекту” та “музики” виникло значно пізніше як “музичний інтелект" в теорії Г. Гарднера [5, 222], однак С. Людкевич у статті “Проблема сучасної музичної культури в Західній Україні” [11, 393] частково розшифрував власне розуміння призначення музики в розвитку української нації та як іiі інтелекту такими тезами: пріоритетність розвитку культури у становленні нації; музика давній і традиційний чинник суспільного виховання; музика і пісня - головні рушії української культури; розвиток національної музичної культури має вагоме суспільне значення; музична фахова школа - невід'ємна частина відродження української освіти загалом.

2. “Калькалатія”(1935) - давньогрецьке поняття, що визначає етичне розуміння музичного мистецтва, С. Людкевич розшифровував фразою 3 доповіді на Першому Українському Педагогічному конгресі у Львові “Організація музичного виховання": "Немає добра без краси, ані правдивої краси без добра" [11, 293]. Апелювання до давньогрецької системи музичного виховання (ідей Піфагора, Платона, Аристотеля) простежується в роботах С. Людкевича принаймні до 1939 р. Зокрема, у статті "Про музикальне виховання" (1921) автор, осмилюючи етичні критерії оцінювання музичного мистецтва,звертався до ідей давньогрецьких філософів Піфагора, Платона, Аристотеля, а також до тез китайського мислителя Конфуція [11, 264 - 268]. Знаковим у тому сенсі є використання цитат із праці “Держава” Платона: “Вона (музика) $\epsilon$ основою державного устрою: іiї занепад потягає за собою упадок державного законного ладу”. I далі: “Два головні чинники музики - мелос і ритм - мають, на думку Арістотеля, рішаючий вплив на психіку чоловіка. Вони або побуджують волю до діла, вправляють в екстаз, або навпаки, утихомирюють страсті, лічать від божевілля та шалу" $[11,265]$. Саме авторитетом античних авторів С. Людкевич обгрунтовує згадані в доповіді на Першому українському педагогічному конгресі “Організація музичного виховання” (1935) поняття емоційно-почуттєвого та інтелектуального впливу музики $[11,293]$. У статті “Проблема сучасної музичної культури України” (1934), розглядаючи суспільно-виховне значення музичного мистецтва, С. Людкевич знову підкреслює ідеї Піфагора та Платона щодо музики як одного з обов’ язкових напрямків освіти “для кожного державного мужа" [11, 393]. Резюмуючи, автор зазначає, що музика формує громадську позицію і виховує патріотизм, “порядкує і рівноважить противенства й пристрасті життя та облагороджує душу” $[11,293]$ та “чим раз більше стає одним з головних чинників і засобів у вихованні молодого покоління від колиски до повного розвою" $[11,266]$.

3. Визначення природній співучий інстинкт дитини зі статті “Наші шкільні співаники” (1905) у С. Людкевича є прикметним із двох позицій. Поперше, важливо тут підкреслити покликання на педагогічні концепції Й.Г. Песталоцці (природовідповідність і розвиваюче навчання) та Ф. В. Фребеля (виховання через гру в період дошкілля). По-друге, автор наголошує на провідній ролі рідного музичного середовища дитини (зокрема, фольклору) у розвитку цього природнього співучого інстинкту. "Саме наука співу, якраз покликана до того, щоб раціонально розвивати природний (підкреслення С. Л. - H. $K$.) співучий інстинкт у дітей, т. $є$ нав'язувати до того, що дитина принесла з рідної хати, до питомої народної пісні... А спеціально в нас, українців, де матеріал пісень народних представляє невичерпне багатство форм пісенних, 3 яких так легко повними руками черпати можна, про се ніяк невільно забувати" [11, 258 - 259].

4. Термін “омузикалення” у статті “Розклад науки сольфеджіо” (1930) [11, 281]) в поясненнях митця має вужчий фаховий сенс, адже йде мова про комплексний розвиток трьох основних фізіологічних первнів, що $є$ в основі музичних здібностей дитини, - ритму, інтонації (звуковисотності) та слуху. 3 цієї позиції варто пригадати визначення предмету “сольфеджіо", яке С. Людкевич подав у примітках: “Іменем “сольфеджіо" обіймаємо ту не тільки у вузькім значенні сольмізовану інтонацію, але щось значно ширше - практичне омузикалення трьома різними дорогами: 1) окремими ритмічними вправами; 2) властиво інтонацією голосом; 3 ) слуховими вправами із застосуванням музичного диктанту" $[11,281]$. Вказані три 
фізіологічні первні $є$ основою трьох частин сольфеджіо у концепції С. Людкевича: ритміки, інтонації та слухових вправ. За цим принципом побудовані, зокрема, “Матеріали до науки сольфеджо і хорового співу” [13]: розділ А ритміка, в т. ч. взірці різних ритмічних структур, вправи і ритмічне читання нот; розділ Б Інтонація, інтонаційні вправи на різні музичні явища та взірці музичної літератури для сольмізації. На жаль, у “Матеріалах" відсутній третій розділ - приклади слухових вправ.

5. Поняття “синтетичної” освіти музиканта в статтях автора, наприклад "Про музикальне виховання" (1921) [11, 267], означало опанування всіх мистецьких і фахових предметів, необхідних для формування музичного світогляду.

Головною рисою музично-педагогічної концепції С. Людкевича у професійній музичній сфері є інтегративність, яку засвідчує зміст цілої низки публікацій та структура відповідних музично-дидактичних матеріалів. Кожен предмет музично-теоретичної системи має власне функціональне призначення: сольфеджіо-спосіб “практичного омузикалення", унаочнення основ музики [11, 281]; теорія (загальні основи музики) - підсумок енциклопедичного типу на першому етапі навчання, іiї структура базується на практиці професійного аналізу музичного твору, володіння яким обов'язкове, передовсім, для виконавців [12;11, 281]; гармонія поділяється на аналітичну (для виконавців) - служить для виховання орієнтації та розуміння музичних творів, та синтетичну (для спеціальності теорія музики) - допомагає розвивати творчу інвенцію [11, 284]; музична естетика - виховує розуміння ідейнозмістового та емоційно-психологічного наповнення складників музичної тканини, їх етосу [10, 151 - 160].

Інтегративні принципи музично-педагогічної концепції С. Людкевича добре простежуються, якщо зіставити, наприклад, зміст предметів сольфеджіо - теорія музики, теорія музики музична естетика. На думку митця, “сольфеджіо - 3 окремими ритмічними й слуховими вправами - це тільки метод практичного унаочнення основ музики, якого ціллю - впоїти й присвоїти живому розумінню й почуттю учеників теоретичні основи... Для науки теорії остало би тільки завдання впорядкувати усе практично засвоєне знання в загальній енциклопедичній схемі при кінці нижчого курсу, а відтак у розширенім виді - на середнім курсі гармонії і других дисциплін" [11, 281]. Отже, “Загальні основи музики...” є по-суті теоретичною частиною матеріалів С. Людкевича зі сольфеджіо та хорового співу. Це засвідчує співпадіння самої концепції побудови та послідовність розділів: ритміці та систематиці в теорії відповідають самостійні ритмічні та інтонаційні вправи у сольфеджіо. У тому ж напрямку варто розглядати й музичну естетику, адже, як твердив С. Людкевич, на першому етапі “мусимо перш усього провірити з погляду естетичного вражіння всі головні елементи, з яких складається музика: ритміку з ї підсумками (тактовими мірами, динамікою наголосів та темпом), тон із усіма його аксесуарами (висотою, краскою еtс.), врешті основні комбінації тону і ритміки в одноголосній мелодії, відтак гармонії і поліфонії...” [10, 151].

Таблиця 1

Порівняння змісту “Загальних основ музики (теорії музики)"та “Основ музичної естетики” С. Людкевича

\begin{tabular}{|c|c|}
\hline Загальні основи музики [13] & Музична естетика $[10,151-160]$ \\
\hline $\begin{array}{l}\text { Увід (встуn) - суть музики, її основні елементи, тобто звук, і } \\
\text { найважливіші поняття музичного мистецтва }\end{array}$ & $\begin{array}{l}\text { Вступ. Напрямки науки естетики. Тон. } \\
\text { Висота тонів. Висота і протяжність тону. } \\
\text { Висота і сила тону. Естетична краса тону. }\end{array}$ \\
\hline $\begin{array}{l}\text { Ритміка - ритм і такт, поділ тривалостей, види такту, сильні } \\
\text { i слабі долі, затакт та ін., темп, тактування, динамічні } \\
\text { відтінки }\end{array}$ & $\begin{array}{l}\text { Ритміка в музиці. Наголоси, їх характер і } \\
\text { прикмети. Динамічна сторона ритму. Темп. }\end{array}$ \\
\hline $\begin{array}{l}\text { Систематика - система тонів, звукоряд, письмо, альтерація, } \\
\text { основні лади, квінтове коло, практичне використання скаль - } \\
\text { мелодія, модуляція, транспозиція, прикраси мелодії, } \\
\text { інтервали, обертоновий ряд, акорди }\end{array}$ & $\begin{array}{l}\text { Мелодія. "Краса” і “виразовість” мелодії. } \\
\text { Поліфонія. Гармонія. Естетика тональних } \\
\text { співвідношень. } \quad \text { Тонально-модуляційні } \\
\text { ефекти гармонії. }\end{array}$ \\
\hline \multicolumn{2}{|l|}{ Краска тону - виконавські засоби } \\
\hline $\begin{array}{l}\text { Музичні жанри-структурні елементи форми, гомофонні і } \\
\text { поліфонічні базові форми; форми нового стилю- allegro, } \\
\text { рондо, циклічні форми, романтичні i модерні форми, } \\
\text { вокальні і вокально-інструментальні форми, форми } \\
\text { церковної музики }\end{array}$ & $\begin{array}{l}\text { Музична “форма” (т. є. побудова твору як } \\
\text { чинник естетичного враження) }\end{array}$ \\
\hline Музичний словник & \\
\hline
\end{tabular}


Навчання, за концепцією С. Людкевича, повинно охоплювати два етапи. В центрі першого 3 них - нормативна ритміка і діатонічна звукова система, яка включає також одно-, дво- i триголосний спів та системний виклад теоріїв кінці курсу. Другий етап має бути присвячений складнішим явищам у сфері ладо-тональної системи, інтонування, метроритму і гармонії (хроматика, альтерація, поліритмія, поліметрія, різноманітні види гомофонно-гармонічного та поліфонічного багатоголосся). Важливо також те, що вся методика має бути спрямована на вироблення чуття природньо-акустичного зв'язку елементів, за словами С. Людкевича, “слухової вісі”, а отже повинна формувати узгоджену та цілісну систему музичних знань і розвивати мислення. "Основою цілої нашої музичної освіти був і буде слух релятивний: не “попадання” поодиноких тонів чи відірваних інтервалів, але можливо повний розвій релятивного слуху в напрямі органічного розуміння й відчуття цілої системи гармонічних зв'язків...” [11, 270].

Музично-педагогічну концепцію С. Людкевича доповнює його бачення принципів побудови музично-теоретичних підручників, яку можна узагальнити, наприклад, за рецензією на популярні хрестоматії з гармонічного аналізу [11, 345 - 350]: уникання абстрактного формалізму й конструктивізму, історичний принцип упорядкування матеріалу, врівноваження прикладів різних епох та стилів, поступеневий виклад від найпростішого до найскладнішого, необхідність взірцевих прикладів із поясненнями на початку розділів, зв'язок теоретичного (гармонічного) явища та його виразового змісту, достатній естетичний рівень конструктивних вправ.

Висновки. Отже, питання національного музичного виховання й педагогіки утворюють своєрідну наскрізну лінію діяльності та творчої спадщини С. Людкевича. Вихідною позицією для митця було твердження про суспільну важливість розбудовування національної системи музичної освіти 3 огляду на етичний вплив музичного мистецтва та його вагому роль в соціокультурному розвитку українців. Це спонукало його обговорювати одночасно різні за призначенням напрямки музичної освіти - масове виховання через музику, спів у загальній школі, а також професійну освіту, в царині якої С. Людкевич поєднував організаційну (у ВМІ ім. Миколи Лисенка), науково-методичну й дидактичну діяльність. 3 цього ж огляду митець значну увагу приділяв розробленню національних взірців навчальної літератури з основних музично- теоретичних дисциплін (спів, сольфеджіо, теорія музики, гармонія, естетика).

Підкреслення етично-виховних засад музичного мистецтва, спираючись на традиції античних мислителів, визначення принципів розвитку природніх музичних здібностей та мислення, усвідомлення вагомого національного суспільно-культурного призначення музики, інтегроване трактування основних музичнотеоретичних предметів у сфері професійної освіти - все це не лише підносить спадщинуС. Людкевича у число знакових музично-педагогічних концепцій XX ст., але й актуалізує виховні ідеї автора в конотексті сучасної масової та, особливо, професійної музичної освіти.

\section{ЛІТЕРАТУРА}

1. Баб'юк Л. Музично-педагогічна діяльність С. П. Людкевича. Творчість С. Людкевича: Зб.статей / Упоряд. М. Загайкевич. Київ, 1979. C. $184-195$.

2. Бермес І. Станіслав Людкевич про музичне виховання дітей.Наукові записки ТНПУ ім. М. Гнатюка: Серія мистецтвознавство. Вип. 1(10). Тернопіль, Київ, 2003. С. 47-51.

3. Витвицький В. Музикознавчі праці. Публіцистика./ упор. Л. Лехник. Львів, 2003. 400 с.

4. Гамкало I. Мої спогади про Станіслава Людкевич. Художня культура. Актуальні проблеми. Київ, 2010. Вип. 7. С. 347-359.

5. ГарднерГ. Множинні інтелекти. Теорія упрактиці: хрестоматія. Київ: Мегатайп, 2004. 288 с.

6. Гнатів Т. Станіслав Людкевич. Штрихи до портрета. Мистецтвознавство України. Київ, 2013. Вип. 13. С. 90-96.

7. Книга протоколів Музичного товариства імені Миколи Лисенко/ Упор., вст. сл., комент. Я. Горака.Тернопіль: Астон, 2014. 424 с.

8. Кобрин Н. В. Музична культура в національному русі галицьких українців (1891 1939). Автореферат дисертації на здобуття наук. ступеня канд. історичних наук за спеціальність 07.00.01 - історія України. Львів, 2010. 19 с.

9. Ластовецький М. А. Станіслав Людкевич у спогадах Миколи Колесси. Українська культура: минуле, сучасне, шляхи розвитку. Рівне, 2012. Вип. 18(1). С. 54-57.

10. Людкевич С. Дослідження, статті, рецензії, виступи: у 2 т. / упор. 3. Штундер. Львів: видавництво М. Коць, 1999. Т. 1.496 с.

11. Людкевич С. Дослідження, статті, рецензії, виступи: у 2 т. / упор. 3. Штундер. Львів: видавництво М. Коць, 2000. Т. 2. 816 с.

12. Людкевич С. Загальні основи музики (теорія музики). Коломия, 1921. 136 с. 
13. Людкевич С. Матеріяли до науки сольфеджо і хорового співу. І курс: Тактова ритміка. Діятоніка Dur-moll. Краків, Львів: Українське видавництво, 1942. 63 с.

14. Михайличенко О. В. Музично-педагогічна діяльність українських композиторів і виконавців другої половини XIX - початку XX ст.: історичні нариси. Суми: Видавничо-виробниче підприємство "Мрія-1", 2005. С. 72-79.

15. Цегельський С. Музичне життя Перемишля. Перемишль - західний бастіон України. / Ред. проф. Б. Загайкевич. Нью-Йорк; Філадельфія, 1961. C. 315-334.

16. Штундер 3. Станіслав Людкевич. Життя i творчість: у 2 т. / 3. Штундер. Львів, 2005. Т. 1 (1879-1939). 36 c.

\section{REFERENCES}

1. Babiuk, L. (1979). Muzychno-pedahohichna diialnist S. P. Liudkevycha [Stsnislav Liudkevych musical and pedagogical activity]. Stanislav Liudkevych creativ works. (Ed.).M. Zahaikevych. Kyiv, pp. 184-195. [in Ukrainian].

2. Bermes, I. (2003). Stanislav Liudkevych pro muzychne vykhovannia ditei [Stanislav Liudkevych about musical education of children]. The Scientific Issues of Ternopil Volodymyr Hnatiuk National Pedagogical University. Specialization: Art Studies. vol. 1(10), Ternopil, Kyiv. pp. 47-51. [in Ukrainian].

3. Vytvytskyi, V. (2003). Muzykoznavchi pratsi. Publitsystyka [Musicology. Journalism.]. (Ed.). L. Lekhnyk, Lviv. 400 p. [in Ukrainian].

4. Hamkalo, I. (2010). Moi spohady pro Stanislava Liudkevych [My memories of Stanislav Liudkevych]. Art culture. The topical problems, vol. 7. Kyiv. pp. 347-359. [in Ukrainian].

5. Gardner, G. (2004). Mnozhynni intelekty. Teoriia u praktytsi [Multiple Intelligences: The Theory in Practice]. Kyiv: Mehataip Publ., 288 p. [in Ukrainian].

6. Hnativ, T. (2013). Stanislav Liudkevych. Shtrykhy do portreta [Stanislav Liudkevych. The features of portrait]. Art studies of Ukraine, vol. 13. Kyiv. pp. 90-96. [in Ukrainian].

7. Knyha protokoliv Muzychnoho tovarystva imeni Mykoly Lysenko (2014). [The book of protocols of Mykola Lysenko Music Society]. (Ed). Ya. Horaka, Ternopil: Aston, 424 p. [in Ukrainian].

8. Kobryn, N. V. (2010). Muzychna kultura v natsionalnomu rusi halytskykh ukraintsiv (1891-1939) [Musical culture in the national movement of Halycian Ukrainians (1891-1939)]. Extended abstract of candidate's thesis. Lviv, 19 p. [in Ukrainian].

9. Lastovetskyi, M. A. (2012). Stanislav Liudkevych u spohadakh Mykoly Kolessy [Stanislav Liudkevych in Mykola Kolessa memoirs]. Ukrainian culture: the past, the modern, the ways of development, vol. 18(1). Rivne. pp. 54-57. [in Ukrainian].

10. Liudkevych, S. (1999). Doslidzhennia, statti, retsenzii, vystupy [Research, papers, reviews, speeches]. (Ed.).Z. Shtunder, Lviv, vol.1, 496 p. [in Ukrainian].

11. Liudkevych, S. (1999). Doslidzhennia, statti, retsenzii, vystupy [Research, papers, reviews, speeches]. (Ed.). Z. Shtunder, Lviv, vol. 2, 816 p. [in Ukrainian].

12. Liudkevych, S. (1921). Zahalni osnovy muzyky (teoriia muzyky) [General Fundamentals of Music (Music Theory)]. Kolomyia,136 p. [in Ukrainian].

13. Liudkevych, S. (1942). Materiialy do nauky solfedzho i khorovoho spivu. I kurs: Taktova rytmika. Diiatonika Dur-moll [The materials to the solfege and choral singing training. The first year. Time rhythm. Diatonic Dur-moll]. Krakiv, Lviv: Ukrainian, 63 p. [in Ukrainian].

14. Mykhailychenko, O. V. (2005). Muzychnopedahohichna diialnist ukrainskykh kompozytoriv $i$ vykonavtsiv druhoi polovyny XIX - pochatku XX st.: istorychni narysy. [Musical-pedagogical activity of Ukrainian composers and musicians at the second half of the $19^{\text {th }}$ and the early $20^{\text {th }}$ centuries]. Sumy: "Mriia-1", pp. 72-79. [in Ukrainian].

15. Tsehelskyi, Ye. (1961). Muzychne zhyttia Peremyshlia [The musical life of Peremyshl]. Peremyshl - the western stronghold of Ukraine, (Ed.).B. Zahaikevych. New York; Filadelfia. pp. 315334. [in Ukrainian].

16. Shtunder, Z. (2005). Stanislav Liudkevych. Zhyttia i tvorchist [Stanislav Lyudkevych. The life and creative works]. in 2 vol., Lviv. Vol. 1 (18791939), 636 p. [in Ukrainian].

Стаття надійшла до редакції 20.02.2019

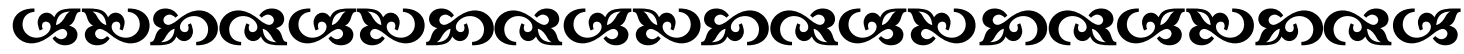

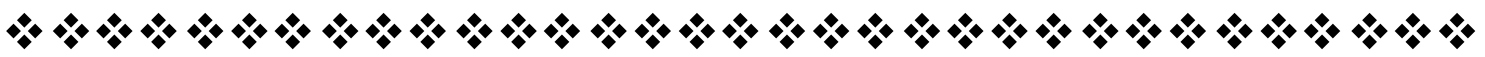

